\title{
THE EFFECT OF ON-STREET PARKING ON U-TURN AREA TOWARDS URBAN ROAD PERFORMANCE (STUDY CASE: AFFANDI STREET, YOGYAKARTA)
}

\author{
Prima J. Romadhona ${ }^{\mathrm{a}^{*}}$ and Tsaqif N. Ikhsan ${ }^{\mathrm{a}}$
}

\begin{abstract}
Affandi St was on high economic activity area. A consequence was the presence of on-street parking at the turning facility (U-turn) caused a conflict in the form of congestion. This research was intended to determine the performance of the road segment, queue length, delay and proposed alternative solutions for improvement. The research was conducted with the field survey method. The analysis was using VISSIM microsimulation refers to Reverse Planning 06/BM/2005 and the level of performance of road performance refers to the Minister of Transport Regulation number PM 96 of 2015. The result indicated that the average vehicle speed of existing conditions VISSIM analysis was 29,26 km/hour for the North to South and 41,43 $\mathrm{km} / \mathrm{hour}$ for the South to North, the average queue length was 22,23 meters, the average delay time was 13,66 seconds. Three alternative solutions were implementing prohibited on-street parking at the U-turn area. From the three solutions, the best one was a solution with a decreasing percentage was $27,84 \%$ for the queue length and $46,53 \%$ for the delay, while the speed increases were $38,54 \%$ for North to South and 20,20\% for South to North.
\end{abstract}

Keywords: Microsimulation, parking, u-turn, vissim

\section{INTRODUCTION}

As a fast-growing city, Yogyakarta has swift improvement especially in the education, trade, and tourism sector. These developments affected the high traffic growth. In this context, traffic becomes busier and transport problems arise, such as insufficient parking spaces. Therefore, many motorists park their vehicles on street [1]. On-street parking had caused the reduction of road capacity [2], traffic conflict [3], traffic delay [4], and deterioration of traffic performance $[5,6,7,8]$.

The deterioration of traffic performance was indicated by the number of congestion-sensitive points. One of the congestion-sensitive points as a result of the parking space on the road body was on a U-turn. U-turn is turning round facilities for maneuvers of vehicle performing that aims to travel to the opposite lane [9] and can be found in the median opening [10]. Limited land and on-street parking restricted the freedom of vehicles [7] to do the U-turn movement directly. One of the streets in Yogyakarta that had a vulnerable point because of on-street parking at turning round (U-turn) facilities was Affandi St.

Affandi St was on a high economic activity level area because there were hotels, restaurants, schools, offices, and shops. According to Yogyakarta RTRW Regional Regulations of 2010, Affandi St was included in the secondary collector road [11]. Affandi St had a separate building (median) with a reversal facility (U-turn). The existence of high economic activities in Affandi St resulted in a demand increase for parking space [12] so that at certain times there was an imbalance between the needs of parking and parking capacity [7]. Therefore, many motorists parking on-street that influenced the traffic disruption such as the reduction in stream speed or capacity of the road [13, 14, 15], especially at locations that happened to be at the U-turn when the vehicle makes a turn.

The purpose of this study was to know the performance of existing road conditions and propose alternative solutions to improve road performance, reduce queues and delays due to on-street parking at the U-turn area.

\section{RESEARCH SIGNIFICANCE}

This paper analyzed the performance of road segment, Uturn, and solutions of on-street parking effect by using VISSIM microsimulation refers to Reverse Planning 06/BM/2005 [16]. The performance level of the road refers to the Minister of Transport Regulation number PM 96 of 2015 [17].

\section{METHODOLOGY}

The research was conducted with a field survey method including traffic volume, on-street parking characteristics, vehicle speed, driving behavior, queue length, and delay.

\section{A. REVOLVING PLANNING GUIDELINES (U- TURN)}

According to the Directorate-General of Highways (2005), median openings are planned to accommodate the vehicle to perform reversal movements on shared road types, cutting and turning movements can be performed.

The reverse plan (U-turn) was based on the 06/BM/2005 Revolving Planning Guidelines (U-Turn) [16].

\section{B. U-TURN TYPE}

U-turn in the middle of the segment with ideal median width that can accommodate the U-turn movement of the vehicle from the inner lane to the second lane of the opposite lane can be seen in Figure 1.

\section{DELAY}

The delay caused by a vehicle making U-turn to the opposite lanes that effect the original lanes can be seen in Table 1.

${ }^{a}$ Civil Engineering Department, Faculty of Transportation and Planning, University of Islamic Indonesia, Sleman, Yogyakarta, Indonesia, 55584. Corresponding author email address: prima_dhona@uii.ac.id 


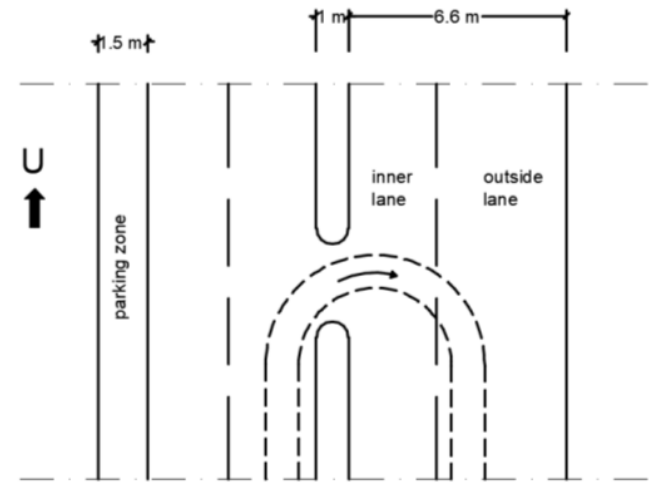

Figure 1. U-Turn Type

Table 1 Vehicle delay [16]

\begin{tabular}{ccc}
\hline \multirow{2}{*}{$\begin{array}{c}\text { Volume Of Average Traffic } \\
\text { Each Lane on the Opponent } \\
\text { Lane }\end{array}$} & \multicolumn{2}{c}{$\begin{array}{c}\text { Delay Because 1 Rotating } \\
\text { Vehicle (sec) }\end{array}$} \\
\cline { 2 - 3 } (Vehicle / hr) & $4 / 2 \mathrm{D}$ & $6 / 2 \mathrm{D}$ \\
\hline 600 & 7,32 & 6,19 \\
\hline 1000 & 9,36 & 8,95 \\
\hline 1400 & 12,04 & 13,63 \\
\hline 1600 & 13,62 & 16,69 \\
\hline
\end{tabular}

\section{QUEUE LENGTH}

The queue length (4/2-way lanes divided) was calculated using the formula below.

Queue Length $=-1,29706+0,09778$ U-turn vehicle waiting time $+0,00214$ vol. al

In Equation (1), the median unit in meters (m), the unit of U-turn vehicle waiting time in seconds, and the unit volume al in pcu/hour.

\section{E. VISSIM}

According to PTV-AG (2011), VISSIM is a multimodal simulated microscopic flow traffic software that can analyze the functioning of private vehicles and public transport with problems such as path configuration, vehicle composition, traffic lights, etc. To make VISSIM a device that is useful for the evaluation of alternative measures [18]. Basis of transport technical measures and effectiveness planning. VISSIM modeling must reflect field conditions, so calibration and validation must be performed. Validation based on vehicle volume that comes with vehicle volume entered in VISSIM. According to Collins (2009), Validation does not meet the requirements if the comparison of data in the field and the simulation has experienced a deviation of more than $15 \%$ [19]. Calibration is performed if the result of the validation does not meet the requirements.

\section{ANALYSIS AND DISCUSSIONS}

\section{A. TRAFFIC CHARACTERISTICS}

One of the useful parameters in the analysis of lane performance was the composition and traffic volume. The composition of Affandi St vehicles during peak hours can be seen in Figure 2 and Figure 3 as follows.

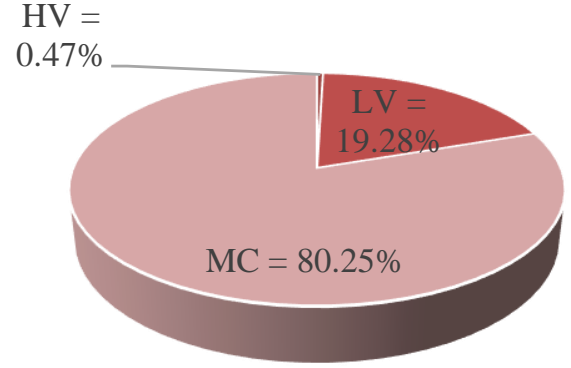

Figure 2 Vehicle Composition at the Peak Hour North to South

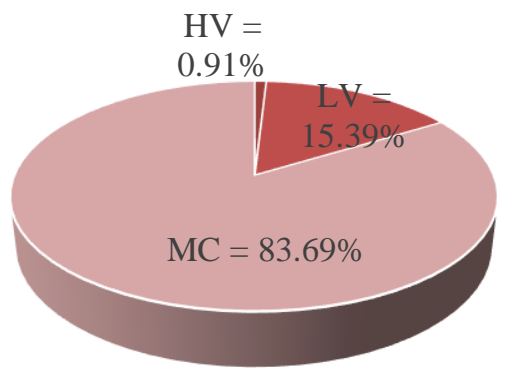

Figure 3 Vehicle Composition at the Peak Hour South to North

\section{B. ANALYSIS OF U-TURN USING REVERSE PLANNING METHOD (U-TURN) 06/BM/2005}

Directorate General of Highways has a special regulatory guideline for reversing rounds to create uniformity in planning a reverse cycle and providing safety to road users. In the guidelines, there is a subsection about the impact of a reversal on a non-eligible median that will result in long queues and delays [20].

\section{VOLUME}

Volume a1 is the deepest lane volume on the same lane with the vehicle that is turning to calculate the length of the row in units of $\mathrm{pcu} /$ hour [16]. The illustrations of the analyzed can be seen on Fig 4-6.

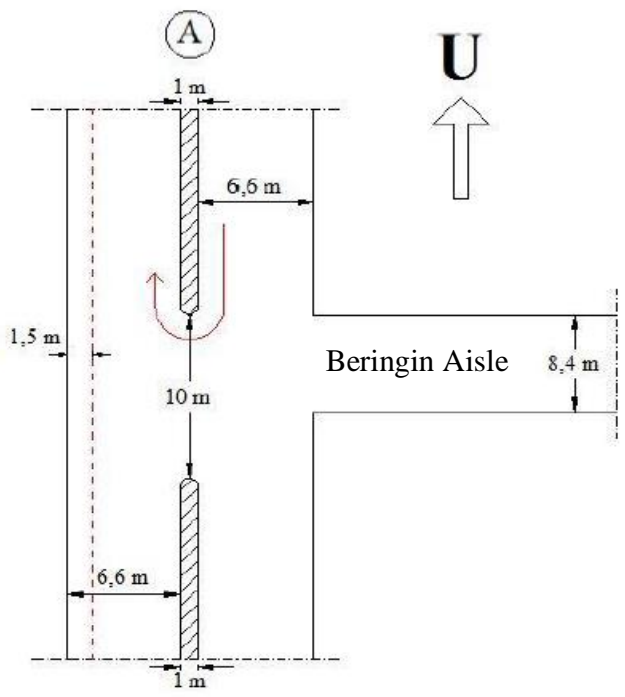

(B)

Figure 4 First u-turn (U1) 


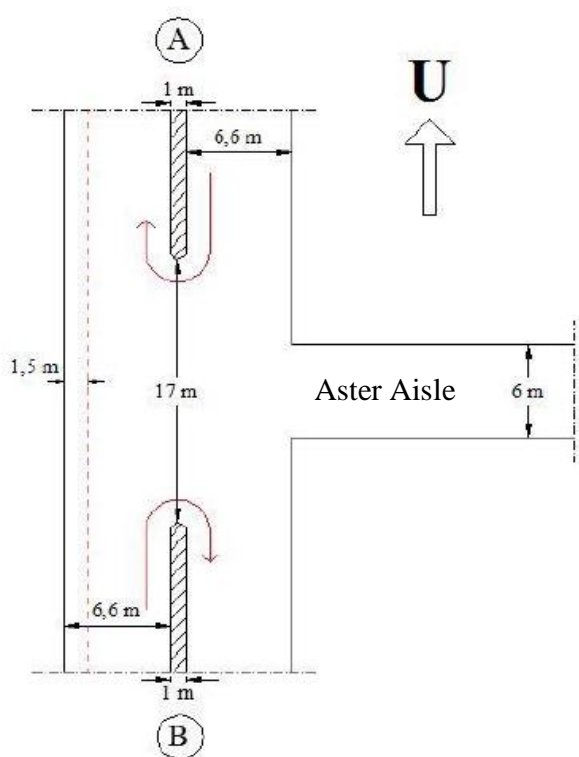

Figure 5 Second u-turn (U2)

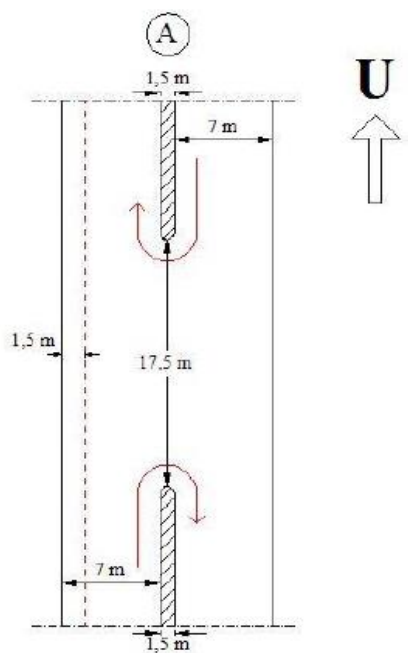

(B)

Figure 6 Third u-turn (U3)

The average traffic volume per runway on the opponent's path is stated in vehicle/hour unit. The volume of the inner row (volume a1) is shown in Table 2 and the average volume in the opposite row is shown in Table 3.

Table 2 Volume a1

\begin{tabular}{cc}
\hline U-Turn Location & Volume a1 (pcu/hour) \\
\hline U1-A (U-S) & 1102,6 \\
U2-A (U-S) & 943,1 \\
U2-B (S-U) & 595,05 \\
U3-A (U-S) & 819,5 \\
U3-B (S-U) & 340,9 \\
\hline
\end{tabular}

Table 3 The average volume in the opposite row

\begin{tabular}{cc}
\hline U-Turn Location & $\begin{array}{c}\text { The average volume in the } \\
\text { opposite row (vehicle/hour) }\end{array}$ \\
\hline U1-A (U-S) & 1208 \\
U2-A (U-S) & 994 \\
U2-B (S-U) & 1726 \\
U3-A (U-S) & 757 \\
U3-B (S-U) & 1076 \\
\hline
\end{tabular}

\section{U-TURN WAITING TIMES}

U-turn waiting times were used in the calculation of the queue length and obtained from field study results which can be seen in Table 4 as follows.

Table 4 U-turn waiting times

\begin{tabular}{cc}
\hline U-Turn Location & U-Turn Waiting Times (s) \\
\hline U1-A & 18,20 \\
U2-A & 15,95 \\
U2-B & 14,37 \\
U3-A & 12,08 \\
U3-B & 14,58 \\
\hline
\end{tabular}

\section{E. QUEUE LENGTH}

Flow a1 U1-A = 1102,6 pcu/hour

U-turn waiting times U1-A $=18,20$ seconds

Queue Length $=-1,29706+0,09778$ U-turn waiting times $+0,00214$ volume a1

$=-1,29706+(0,09778 \times 18,20)+$ $(0,00214 \times 1102,6)$

$=2,84$ meters

The calculation results of Queue Length at other U-turn can be seen in Table 5.

Table 5 Queue length of reverse planning plan method

\begin{tabular}{cc}
\hline U-Turn Location & Queue Length $(\mathrm{m})$ \\
\hline U1-A (U-S) & 2,84 \\
U2-A (U-S) & 2,28 \\
U2-B (S-U) & 1,38 \\
U3-A (U-S) & 1,64 \\
U3-B (S-U) & 0,86 \\
\hline
\end{tabular}

\section{F. DELAY}

The average flow in the opposite row $=1208 \mathrm{pcu} / \mathrm{hour}$ The delay is calculated based on the interpolation of the delay value in Table 1.

Delay $=9,36-\frac{208}{400} x(9,36-12,04)$ $=10,75$ seconds

The calculation results of Delay at other U-turn can be seen in Table 6.

Table 6 Delay of reverse planning plan method

\begin{tabular}{cc}
\hline U-Turn Location & Delay (s) \\
\hline U1-A (U-S) & 10,75 \\
U2-A (U-S) & 9,32 \\
U2-B (S-U) & 14,61 \\
U3-A (U-S) & 8,12 \\
U3-B (S-U) & 9,86 \\
\hline
\end{tabular}

\section{G. ANALYSIS OF U-TURN USING SOFTWARE VISSIM}

The modeling stages using Software VISSIM are as follows.

1. Network Setting

The driver behavior and units were changed according to Indonesian standards, which were vehicle behavior to left side traffic (Figure 7) and units to all metrics (Figure 8). 


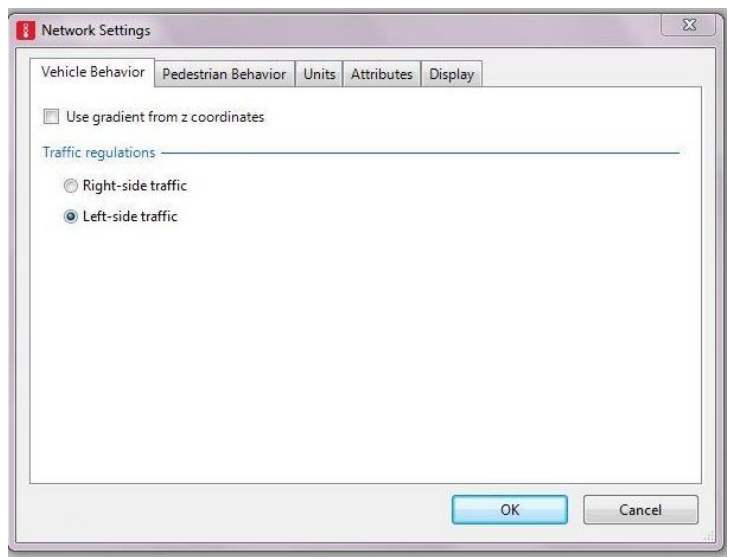

Figure 7 Vehicle behavior settings

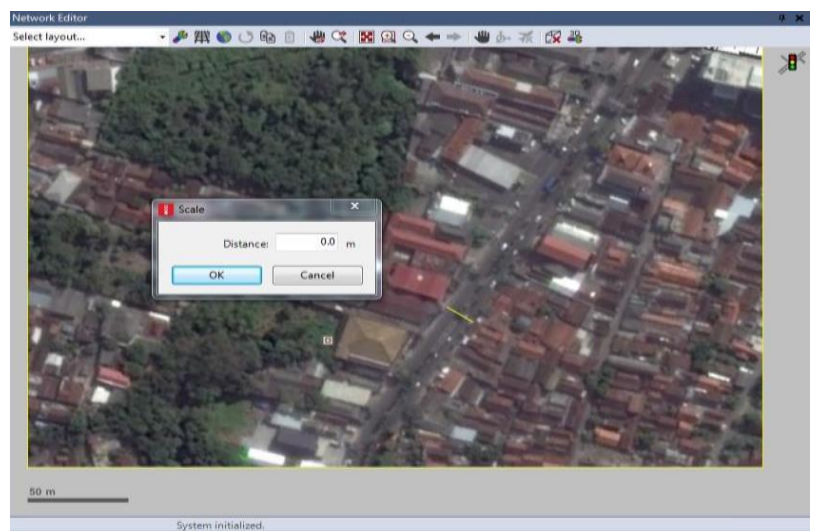

Figure 9 Background image input and set scale

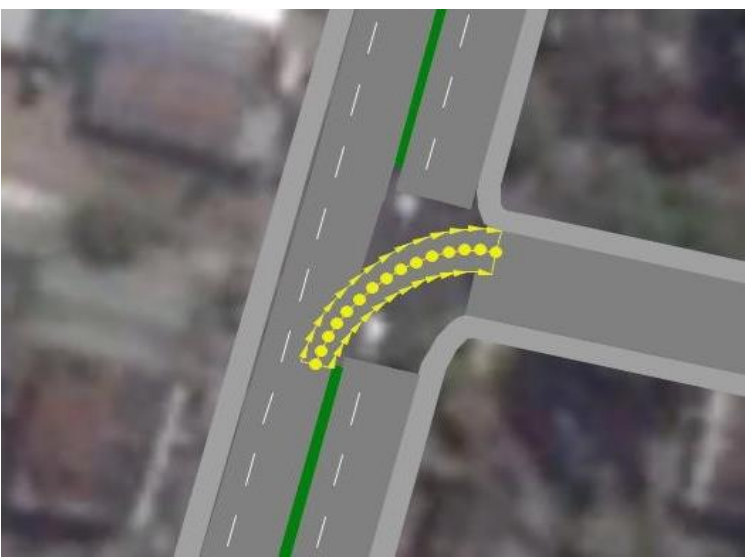

Figure 11 Connectors settings

2. Background Image

The background image was inputted using a survey location map obtained from Google Earth and can be seen in Figure 9.

3. Links and Connectors

Link is road lane at segment or minor road/alley. Connector is a liaison between links. Link settings can be seen in Figure 10 and connector settings can be seen in Figure 11.

4. Traffic Volume and Speed

Traffic volume data that inputted to Vehicle Input setting on Software VISSIM was traffic volume at peak hour on every segment and alley (Figure 12). The vehicle speed from the survey was inputted to the Vehicle Composition setting (Figure 13). After that, the

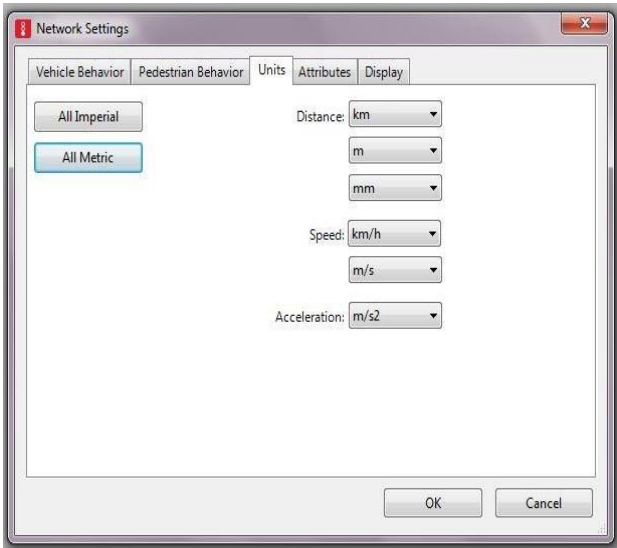

Figure 8 Units settings

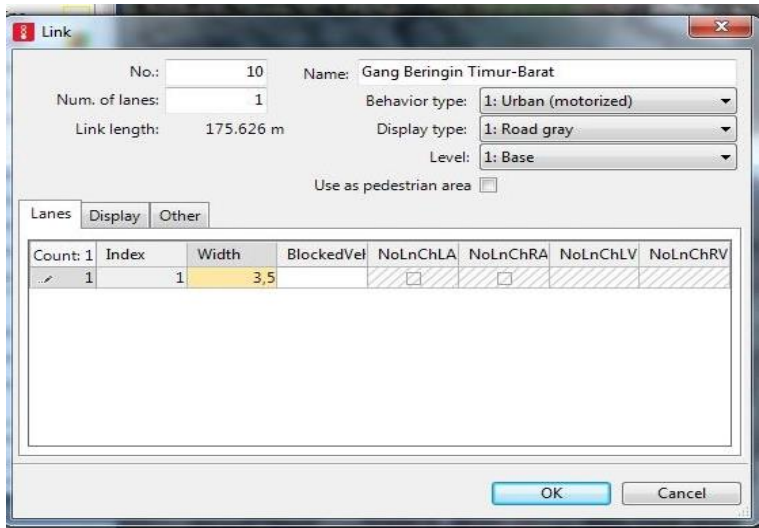

Figure 10 Links settings

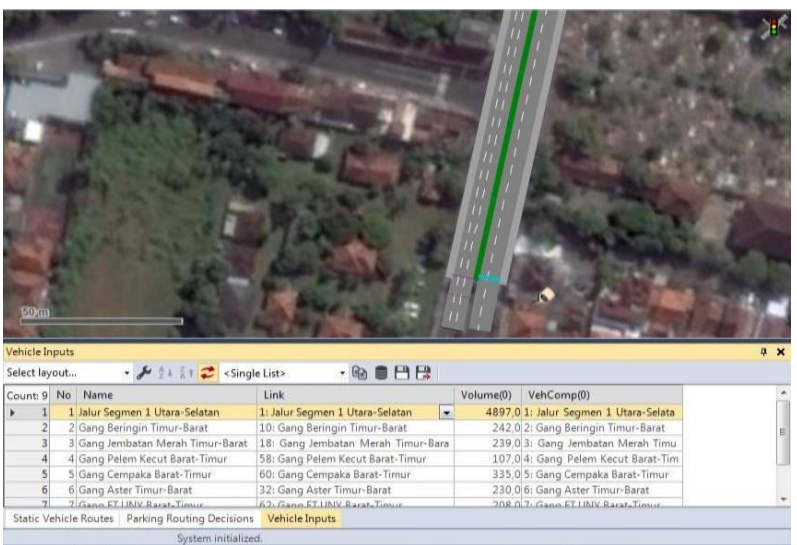

Figure 12 Vehicle inputs

vehicle movement modeling was carried out at the Vehicle Routes setting.

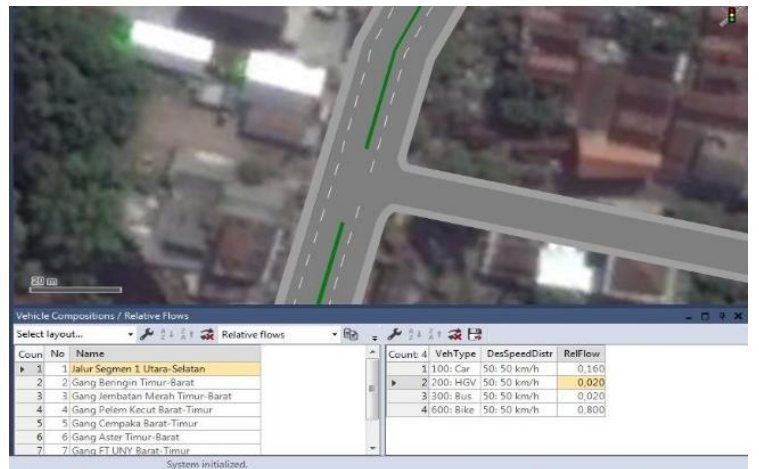

Figure 13 Vehicle composition settings 


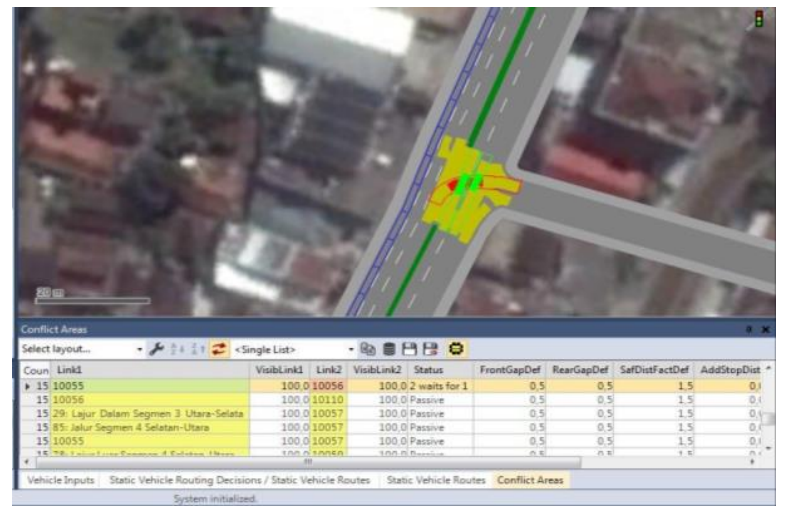

Figure 14 Conflict areas

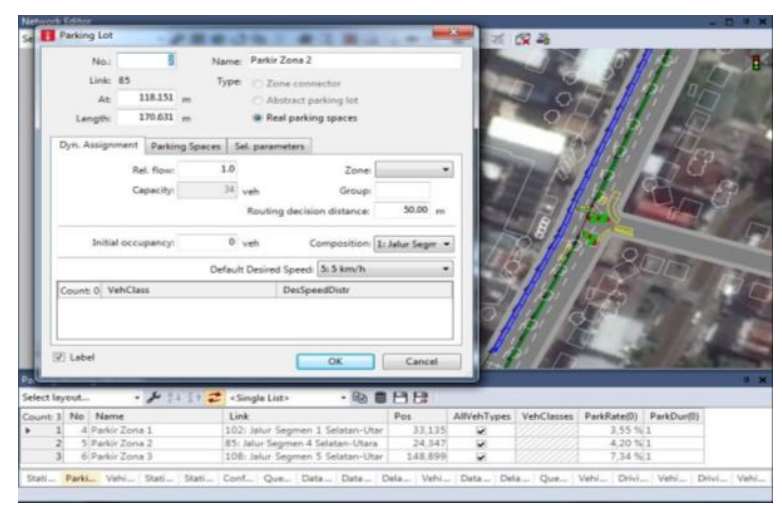

Figure 16 Parking lots settings

Table 7 Field Observations Result for Calibration Input

\begin{tabular}{|c|c|c|}
\hline \multirow{2}{*}{ Parameters } & \multicolumn{2}{|c|}{ Value } \\
\hline & Before & After \\
\hline $\begin{array}{l}\text { Desired position at free } \\
\text { flow }\end{array}$ & $\begin{array}{l}\text { Middle of } \\
\text { lane }\end{array}$ & Any \\
\hline Overtake on same lane & Off & $\begin{array}{l}\text { On Right and } \\
\text { Left }\end{array}$ \\
\hline $\begin{array}{l}\text { Minimum distance } \\
\text { standing (at } 0 \mathrm{~km} / \mathrm{h} \text { ) } \\
(\mathrm{m})\end{array}$ & 1 & 0,6 \\
\hline $\begin{array}{l}\text { Minimum distance } \\
\text { driving } \\
\text { (at } 50 \mathrm{~km} / \mathrm{h} \text { ) (m) }\end{array}$ & 1 & 0,8 \\
\hline $\begin{array}{l}\text { Average standstill } \\
\text { distance }\end{array}$ & 2 & 0,5 \\
\hline $\begin{array}{c}\text { Additive part of safely } \\
\text { distance }\end{array}$ & 2 & 0,8 \\
\hline $\begin{array}{l}\text { Multipliactive part of } \\
\text { safety distance }\end{array}$ & 3 & 1 \\
\hline
\end{tabular}

5. Conflict Area

The conflict areas in this study were at the intersections of segments, alleys, and U-turns. The conflict areas can be seen in Figure 14.

6. Priority Rules

Priority rule is not controlled by signals and is used in a situation when vehicles in different links or connectors need to consider each other [21]. The priority rules settings can be seen in Figure 15.

7. Parking Lots

Modeling a parking area on the street by adjusting the percentage composition of the parking volume with the traffic volume and the parking duration. The parking lots settings can be seen in Figure 16.

8. Reduced Speed Areas

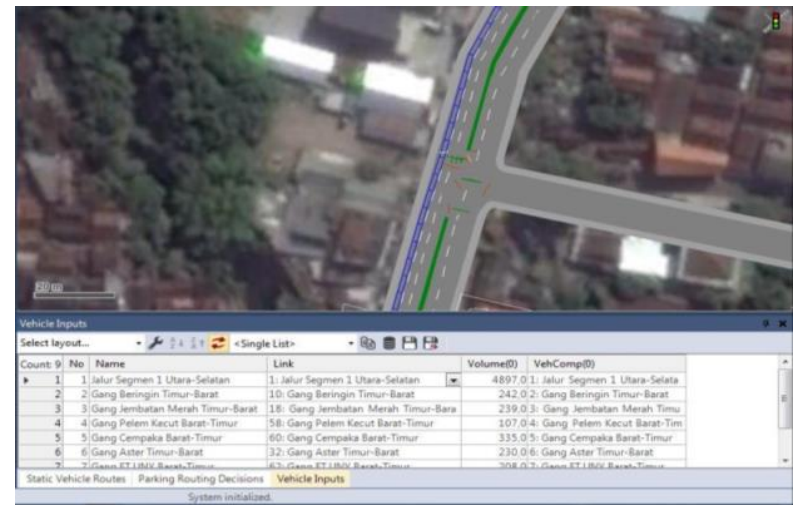

Figure 15 Priority rules settings

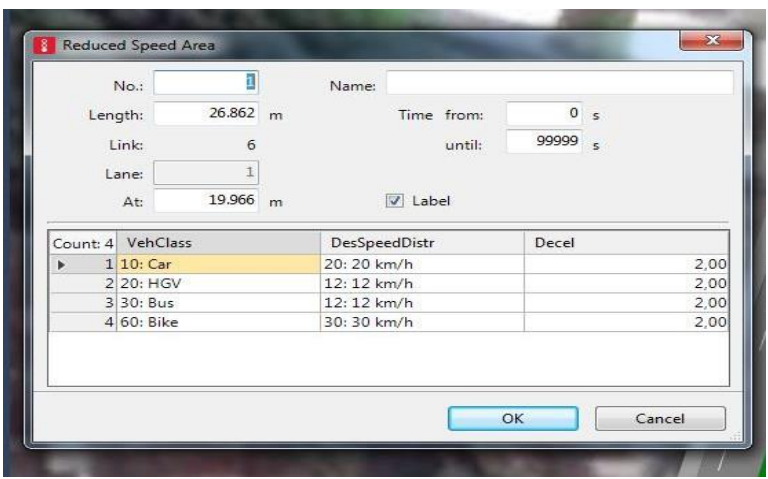

Figure 17 Reduce speed areas settings

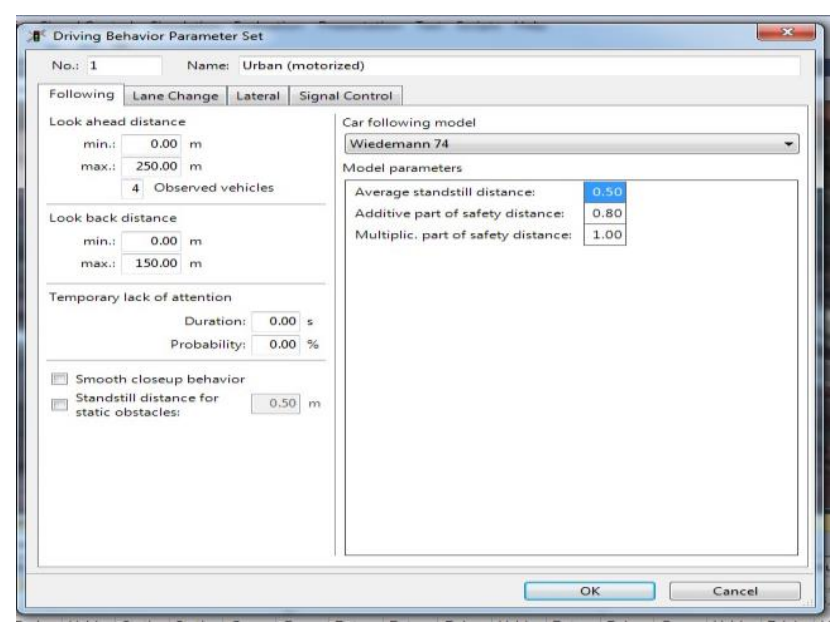

Figure 18 Driving behavior settings

The areas were located at 20 meters of the intersections, turning area, and U-turn area. The reduced speed areas settings can be seen in Figure 17.

9. Driving Behavior

The driving behavior settings of this study can be seen in Table 7 and Figure 18.

10. Evaluation

This parameter was the last stage of VISSIM Modeling. The used tools were vehicle travel time and queue counters on U-turn areas to know the delays and queues length. The evaluation settings can be seen in Figure 19.

11. Validation

The validation result can be seen in Table 8 . 
Table 8 Volume validation result using software VISSIM

\begin{tabular}{ccccc}
\hline Location & $\begin{array}{c}\text { Volume Input } \\
\text { (vehicle/hour) }\end{array}$ & $\begin{array}{c}\text { Volume Output } \\
\text { (vehicle/hour) }\end{array}$ & Deviation & Percentage $(\%)$ \\
\hline Affandi St. (N-S) & 4897 & 4769 & 128 & 2,68 \\
Affandi St. (S-N) & 2410 & 2436 & 26 & 1,07 \\
Beringin Alley & 242 & 248 & 6 & 4,42 \\
Jembatan Merah & 239 & 250 & 11 & 7,00 \\
Alley & 107 & 100 & 7 & 4,01 \\
Pelem Kecut Alley & 335 & 349 & 14 & 2,14 \\
Cempaka Alley & 430 & 421 & 9 & 1,43 \\
Aster Alley & 708 & 698 & 10 & 3,56 \\
FT UNY Alley & 320 & 309 & 11 & \\
Alamanda Alley & & &
\end{tabular}

Table Information:

Deviation : the deviation of volume input and volume output on Software VISSIM

Percentage : Percentage of the deviation of volume input and volume output on Software VISSIM

Table 9 Evaluation result of queue length and vehicle delay in existing condition using VISSIM

\begin{tabular}{lcccc}
\hline SimRun & TimeInt & Location & Queue Length $(\mathrm{m})$ & Veh. Delay $(\mathrm{s})$ \\
\hline Average & $0-3600$ & UI-A Same Lane & 28,79 & 10,94 \\
Average & $0-3600$ & UI-A Opposite Lane & 17,49 & 14,67 \\
Average & $0-3600$ & U2-A Same Lane & 27,44 & 17,73 \\
Average & $0-3600$ & U2-A Opposite Lane & 14,70 & 12,30 \\
Average & $0-3600$ & U2-B Same Lane & 15,99 & 11,15 \\
Average & $0-3600$ & U2-B Opposite Lane & 18,20 & 9,25 \\
Average & $0-3600$ & U3-A Same Lane & 27,25 & 17,09 \\
Average & $0-3600$ & U3-A Opposite Lane & 19,30 & 11,53 \\
Average & $0-3600$ & U3-B Same Lane & 27,70 & 14,91 \\
Average & $0-3600$ & U3-B Opposite Lane & 25,45 & 17,05 \\
\hline \multicolumn{2}{r}{ Average } & & 22,23 & 13,66 \\
\hline
\end{tabular}

\begin{tabular}{cccc}
\multicolumn{4}{c}{ Table 10 The comparison of queue length } \\
\hline Location & $\begin{array}{c}\text { Survey } \\
\text { Data } \\
(\mathrm{m})\end{array}$ & $\begin{array}{c}\text { 06/BM/2005 } \\
(\mathrm{m})\end{array}$ & $\begin{array}{c}\text { Software } \\
\text { VISSIM } \\
(\mathrm{m})\end{array}$ \\
\hline U1-A & 19,86 & 2,84 & 28,79 \\
U2-A & 8,55 & 2,28 & 27,44 \\
U2-B & 14,90 & 1,38 & 15,99 \\
U3-A & 15,00 & 1,64 & 27,25 \\
U3-B & 14,10 & 0,86 & 27,70 \\
\hline
\end{tabular}

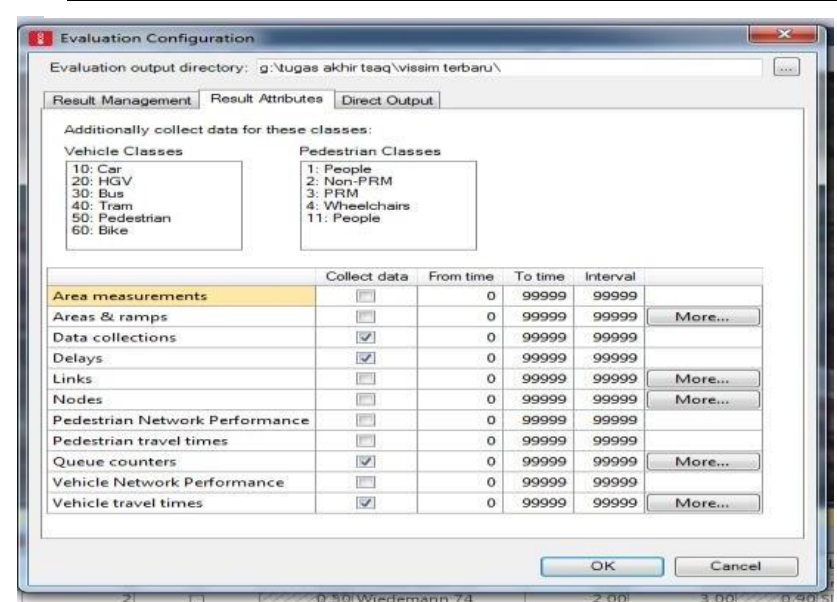

Figure 19 Evaluation settings

Based on Table 8 , all deviations were below $15 \%$, so it was concluded that VISSIM modeling can represent conditions in the field and be used in the analysis.

\section{H. EVALUATION RESULT USING SOFTWARE VISSIM}

The results were queue length and delay time that can be seen in Table 9. The running evaluation was running for 3600 seconds and used 5 times random seed.
Table 11 The comparison of delay

\begin{tabular}{cccc}
\hline Location & $\begin{array}{c}\text { Survey } \\
\text { Data } \\
(\mathrm{m})\end{array}$ & $\begin{array}{c}\text { 06/BM/2005 } \\
(\mathrm{m})\end{array}$ & $\begin{array}{c}\text { Software } \\
\text { VISSIM } \\
(\mathrm{m})\end{array}$ \\
\hline U1-A & 14,95 & 10,75 & 10,94 \\
U2-A & 8,88 & 9,32 & 17,73 \\
U2-B & 9,68 & 14,61 & 11,15 \\
U3-A & 9,92 & 8,12 & 17,09 \\
U3-B & 8,88 & 9,86 & 14,91 \\
\hline
\end{tabular}

I. COMPARISON OF U-TURN ANALYSIS BETWEEN SURVEY DATA, 06 / BM / 2005 REVERSE PLANNING METHOD (U-TURN), AND SOFTWARE VISSIM

The comparative variables were the queue length and the delay which can be seen in Table 10 as follows. Table 10 shows the length of the queue between the three data had a significant difference. The result of the length of the queue with the Reversal Planning Method 06 / BM / 2005 was smaller than the VISSIM output result. It was because the reverse cycle planning method 06 / BM / 2005 calculated the length of the queue based on the row with one row, while the VISSIM simulation calculated the length of the queue based on the queue of two lanes in the same path.

Between the two results of the queue, the VISSIM output results were closer to the results of the field study (primary data). Based on Table 11 shows that the delay varies between the two methods. The result of the delay of method 06 / BM / 2005 was obtained by interpolation of delay data, while the delay of the VISSIM method was the average delay of the queue of vehicles to perform a reversal.

\section{J. PERFORMANCE ANALYSIS OF THE STREET OF EXISTING CONDITION}

The speed used was the average vehicle speed. The speed of the vehicle was also calculated based on the direction of travel of the 
Table 13 Comparison of queue length between existing condition, alternative I, II and III

\begin{tabular}{|c|c|c|c|c|c|c|c|}
\hline \multirow{3}{*}{ Location } & \multirow{3}{*}{$\begin{array}{l}\text { Existing condition VISSIM } \\
(\mathrm{m})\end{array}$} & \multicolumn{6}{|c|}{ Alternative Solutions (VISSIM) } \\
\hline & & \multicolumn{2}{|c|}{ Alternative I } & \multicolumn{2}{|c|}{ Alternative II } & \multicolumn{2}{|c|}{ Alternative III } \\
\hline & & Result (m) & $\begin{array}{c}\text { Decrease } \\
(\%)\end{array}$ & Result (m) & $\begin{array}{c}\text { Decrease } \\
(\%)\end{array}$ & Result (m) & $\begin{array}{c}\text { Decrease } \\
(\%)\end{array}$ \\
\hline U1-A Same Lane & 28,79 & 20,58 & 28,52 & 19,90 & 30,88 & 18,32 & 36,37 \\
\hline U1-A Opponent Lane & 17,49 & 16,77 & 4,12 & 16,84 & 3,72 & 13,82 & 20,98 \\
\hline U2-A Same Lane & 27,44 & 17,43 & 36,48 & 13,88 & 49,42 & 15,11 & 44,93 \\
\hline U2-A Opponent Lane & 14,70 & 12,12 & 17,53 & 14,18 & 3,54 & 14,00 & 4,76 \\
\hline U2-B Same Lane & 15,99 & 16,21 & $-1,38$ & 14,66 & 8,32 & 13,79 & 13,76 \\
\hline U2-B Opponent Lane & 18,20 & 17,83 & 2,03 & 15,39 & 15,44 & 14,74 & 19,01 \\
\hline U3-A Same Lane & 27,25 & 21,11 & 22,53 & 16,99 & 37,65 & 12,62 & 53,69 \\
\hline U3-A Opponent Lane & 19,30 & 18,73 & 2,95 & 18,63 & 3,45 & 18,32 & 5,08 \\
\hline U3-B Same Lane & 27,70 & 19,58 & 29,31 & 15,12 & 45,42 & 12,22 & 55,88 \\
\hline U3-B Opponent Lane & 25,45 & 26,11 & $-2,62$ & 20,59 & 19,09 & 19,35 & 23,94 \\
\hline Average & 22,23 & 18,65 & 13,95 & 16,62 & 21,69 & 15,23 & 27,84 \\
\hline
\end{tabular}

Table information:

Decrease : Percentage decrease of queue length of alternative solution due to the existing state of VISSIM

: There was an increase in the length of the queue (meters) of the solution alternative results of the existing state of VISSIM

Table 14 Comparison of delay between existing condition, alternative I, II and III

\begin{tabular}{|c|c|c|c|c|c|c|c|}
\hline \multirow{3}{*}{ Location } & \multirow{3}{*}{$\begin{array}{l}\text { Existing } \\
\text { condition } \\
\text { VISSIM } \\
(\mathrm{m})\end{array}$} & \multicolumn{6}{|c|}{ Alternative Solutions (VISSIM) } \\
\hline & & \multicolumn{2}{|c|}{ Alternative I } & \multicolumn{2}{|c|}{ Alternative II } & \multicolumn{2}{|c|}{ Alternative III } \\
\hline & & Result (s) & $\begin{array}{c}\text { Decrease } \\
(\%)\end{array}$ & Result (s) & $\begin{array}{c}\text { Decrease } \\
(\%)\end{array}$ & Result (s) & $\begin{array}{c}\text { Decrease } \\
(\%)\end{array}$ \\
\hline U1-A Same Lane & 10,94 & 7,69 & 29,75 & 7,78 & 28,95 & 7,59 & 30,60 \\
\hline U1-A Opponent Lane & 14,67 & 10,36 & 29,38 & 13,95 & 4,88 & 12,47 & 15,00 \\
\hline U2-A Same Lane & 17,73 & 7,98 & 54,99 & 5,25 & 70,37 & 5,18 & 70,81 \\
\hline U2-A Opponent Lane & 12,30 & 10,51 & 14,59 & 10,92 & 11,25 & 11,20 & 8,92 \\
\hline U2-B Same Lane & 11,15 & 10,23 & 8,29 & 10,38 & 6,90 & 10,23 & 8,30 \\
\hline U2-B Opponent Lane & 9,25 & 7,56 & 18,24 & 5,07 & 45,22 & 5,05 & 45,41 \\
\hline U3-A Same Lane & 17,09 & 16,81 & 1,64 & 4,96 & 70,95 & 4,65 & 72,78 \\
\hline U3-A Opponent Lane & 11,53 & 10,89 & 5,55 & 4,26 & 63,05 & 3,93 & 65,92 \\
\hline U3-B Same Lane & 14,91 & 14,12 & 5,33 & 4,45 & 70,15 & 4,10 & 72,50 \\
\hline U3-B Opponent Lane & 17,05 & 15,25 & 10,56 & 4,48 & 73,70 & 4,25 & 75,07 \\
\hline Average & 13,66 & 11,14 & 17,83 & 7,15 & 44,54 & 6,86 & 46,53 \\
\hline
\end{tabular}

Table information:

Decrease : Percentage decrease of queue length of alternative solution due to the existing state of VISSIM

Table 15 Comparison of vehicle speed between existing condition, alternative I, II and III

\begin{tabular}{|c|c|c|c|c|c|c|c|c|}
\hline \multirow{3}{*}{ Traffic Direction } & \multicolumn{8}{|c|}{ Vehicle Speed } \\
\hline & \multirow{2}{*}{$\begin{array}{c}\text { Survey } \\
\text { Data } \\
(\mathrm{km} / \mathrm{h})\end{array}$} & \multirow[b]{2}{*}{$\begin{array}{l}\text { Existing VISSIM } \\
(\mathrm{km} / \mathrm{h})\end{array}$} & \multicolumn{2}{|c|}{ Alternative I } & \multicolumn{2}{|c|}{ Alternative II } & \multicolumn{2}{|c|}{ Alternative III } \\
\hline & & & $\begin{array}{l}\text { Result } \\
(\mathrm{km} / \mathrm{h})\end{array}$ & $\begin{array}{c}\text { Decrease } \\
(\%)\end{array}$ & $\begin{array}{l}\text { Result } \\
(\mathrm{km} / \mathrm{h})\end{array}$ & $\begin{array}{c}\text { Decrease } \\
(\%)\end{array}$ & $\begin{array}{l}\text { Result } \\
(\mathrm{km} / \mathrm{h})\end{array}$ & $\begin{array}{c}\text { Decrease } \\
(\%)\end{array}$ \\
\hline North to South & 29,53 & 29,26 & 42,46 & 31,09 & 47,51 & 38,25 & 47,61 & 38,54 \\
\hline South to North & 35,36 & 41,43 & 51,22 & 19,11 & 51,44 & 19,45 & 51,92 & 20,20 \\
\hline
\end{tabular}

Table information:

Decrease : Percentage decrease of queue length of alternative solution due to the existing state of VISSIM

vehicle. Speed value VISSIM obtained from the result of the data collection on each installation of the data collection point. The output results of the speed of the existing state in VISSIM can be seen in Table 12.

Table 12 Performance of Affandi St in existing condition

\begin{tabular}{ccccc}
\hline $\begin{array}{c}\text { Traffic } \\
\text { Direction }\end{array}$ & $\begin{array}{c}\text { Survey Data } \\
(\mathrm{km} / \mathrm{h})\end{array}$ & $\begin{array}{c}\text { Level of } \\
\text { Service }\end{array}$ & $\begin{array}{c}\text { Output } \\
\text { VISSIM } \\
(\mathrm{km} / \mathrm{h})\end{array}$ & $\begin{array}{c}\text { Level of } \\
\text { Service }\end{array}$ \\
\hline $\begin{array}{c}\text { North to } \\
\text { South }\end{array}$ & 29,53 & $\mathrm{E}$ & 29,26 & $\mathrm{E}$ \\
$\begin{array}{c}\text { South to } \\
\text { North }\end{array}$ & 35,36 & $\mathrm{E}$ & 41,43 & $\mathrm{E}$ \\
\hline
\end{tabular}

\section{K. ALTERNATIVE SOLUTIONS}

Three alternative solutions were used to improve road performance and reduce the length of the queue and delay.

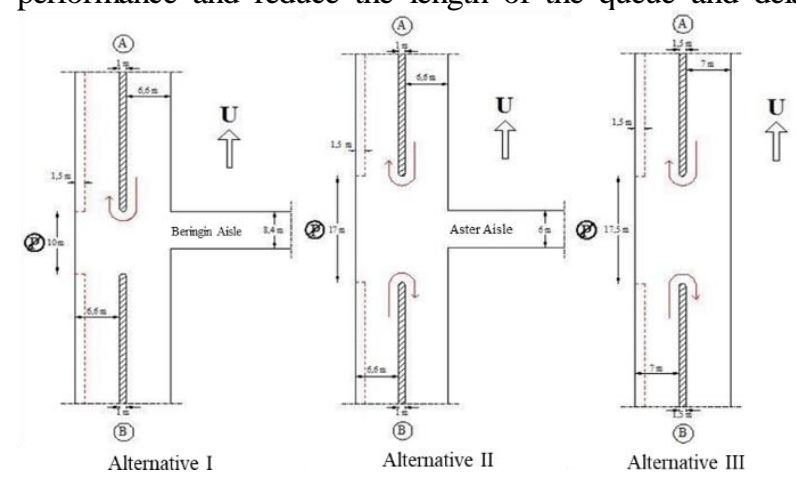

Figure 20 Alternative I, II, and III 
Alternative I was to prohibit on-street parking at a median opening along the width of the median opening itself. Alternative II was to prohibit on-street parking at 5 meters before opening the median to 5 meters after opening the median and Alternative III was to prohibit on-street parking at 10 meters before opening the median to 10 meters after the median opening. The comparison of the existing condition and the alternative solutions can be seen in Table 13 for the parameter of queue length, Table 14 for the parameter of delay, and Table 15 for the parameter of vehicle speed. The figure of each alternative can be seen in Figure 20.

Alternative solutions succeeded in reducing the queue length of the existing condition with the largest average percentage of decline found in alternative III was $27,84 \%$.

Alternative solutions succeeded in reducing the value of delay from the existing condition with the largest average percentage of decline found in alternative III was $46,53 \%$.

The result of alternative analysis succeeded in increasing the speed value of the existing condition of VISSIM with the highest percentage increase in alternative III was $38,54 \%$ for the North to the South direction with the existing condition of $29,26 \mathrm{~km} / \mathrm{h}$ increased to $47,61 \mathrm{~km} / \mathrm{h}$ and level of service E. For the South to the North direction, the percentage increase in alternative III was $20,20 \%$ with the existing condition of $41,43 \mathrm{~km} / \mathrm{h}$ increased to $51,92 \mathrm{~km} / \mathrm{h}$ and level of service $\mathrm{D}$.

Based on Table 13, Table 14, and Table 15, the result of the three alternative solutions showed similar results which were reducing the length of the queue, the delay, and the average speed. As a road performance parameter, it indicated an increase in speed. The increase of parking ban showed a good result in increasing the road performance. The recommendation is to use alternative III, because it showed the largest decrease in queue length and delay, and showed the greatest speed increase.

\section{CONCLUSIONS}

The performance of the Affandi St segment based on the speed parameter for the existing situation was lower than the specification of the Regulation of the Minister of Transportation Number 96 of 2015, which was obtained the level of service of $\mathrm{C}$. The analyzed result using VISSIM software showed that the average vehicle speed of the existing situation was $29,26 \mathrm{~km} / \mathrm{h}$ for the North to the South with the level of service E and $41,43 \mathrm{~km} / \mathrm{h}$ for South to North with the level of service E.

The alternative solutions to increase road performance were devised with VISSIM Software. The obtained solutions were three alternatives that prohibiting parking in the street body in the U-turn area. Alternative I along the width of the median opening itself, alternating II over the width of the median opening plus 5 meters per side and the alternative III over the width of the median opening plus 10 meters per side. The best alternative from the three solutions was alternative III with the average decrease rate of the existing condition of VISSIM equal to $27,84 \%$ for queue length and $46,53 \%$ for delay value while vehicle speed increases. The existing state of VISSIM with a percentage increase rate of $38,54 \%$ for the North to South with the level of service E and 20,20\% for the South to the North with the level of service D. It can be concluded that the parking ban on the road body can improve the performance of the road.

\section{REFERENCES}

[1] S. Biswas, S. Chandra, and I. Ghosh, "Effects of OnStreet Parking in Urban Context: A Critical Review," Transportation in Developing Economies, vol.3, no. 10, 2017. DOI: 10.1007/s40890-017-0040-2

[2] S. Wijayaratna, "Impacts of On-street Parking on Road Capacity," Australasian Transport Research Forum 2015 Procedings, 30 Sep-2 Oct 2015, Sydney, Austalia.

[3] Y. Cao, Z. Z. Yang, and Z. Y. Zuo, "The effect of curb parking on road capacity and traffic safety," European Transport Research Review, vo. 9, no. 4, 2017. DOI: $10.1007 / \mathrm{s} 12544-016-0219-3$

[4] J. Cao, M. Menendez, and V. Nikias, "The effects of on-street parking on the service rate of nearby intersections," Journal of Advanced Transportation, vol. 50, pp: 406-420, 2016. DOI: 10.1002/atr.1329

[5] Sugiarto and T. Limanoond, "Impact of On-street Parking on Urban Arterial Performance: A Quantitative Study on Travel Speed and Capacity Deterioration", Aceh International Journal of Science and Technology, vol. 2, no. 2, pp. 63-69, August 2013. DOI: 10.13170/AIJST.0202.04

[6] S. Sulistyono, H. Sulistio, L. Djakfar, A. Wicaksono, and R. E. Badriani, "On street parking and its impact on road performance," MATEC Web of Confereces 181, 06008, 2018. https://doi.org/10.1051/matecconf/201818106008

[7] A. Winaya, "On-Street Parking and Traffic Flow Performance at Kapasan Shopping Area Surabaya," Journal of Advanced Civil and Environmental Engineering, vol. 3, no. 1, pp. 9-16. Mar. 2020.

[8] I. G. R. Purbanto, "Characteristic of on-steet parking and its effect on road segment performance," Jurnal Ilmiah Teknik Sipil, vol. 16, no. 2, pp. 167-176, Juli 2012.

[9] Rhaptyalyani, "Evaluation of the performance of $u$ turn movement using vissim simulation program; a case study at Burlian Road, Palembang, Indonesia," The $15^{\text {th }}$ FSTPT International Symposium, Nov 23-24 2012, STTD Bekasi.

[10] R. H. Della, Hanafiah, J. Arliansyah, and R. Artiansyah, "Traffic performance analysis of u-turn and fly over u-turn scenario; a case study at Soekarno Hatta Road, Palembang, Indonesia," Procedia Engineering, vol. 125, pp. 461-466, 2015. Available: www. sciencedirect.com

[11] Yogyakarta City Government. Spatial Plan of Yogyakarta City. Yogyakarta: Yogyakarta City Government, 2010.

[12] K. J. Herin and J. Akkara, "Study of on-street and offstreet parking choice behavior," International Journal of Advanced Research in Computer and Communication Engineering, vol. 8, no. 1, Jan. 2019.

[13] M. L. M. Chiguma, "Analysis of side friction impacts on urban roads: Case study Dar-es-Salaam," $\mathrm{PhD}$ dissertation, KTH, Stockholm, 2007.

[14] J. Rudjanakanoknad, "Analysis of factors affecting street bottleneck capacity through oblique cumulative plots," Journal of the Eastern Asia Society for Transportation Studies, vol. 8, pp. 1621-1631, 2010. 
[15] J. Chen, Z. Li, H. Jiang, S. Zhu, and W. Wang, "Simulating the impacts of on-street vehicle parking on traffic operations on urban streets using cellular automation," Physica A: Statistical Mechanics and its Applications, vol. 468, pp. 880-891, 2017. DOI: 10.1016/j.physa.2016.11.060

[16] Directorate General of Highways. Reversal Planning (U-Turn). Jakarta: Directorate General of Highways, 2005.

[17] Minister of Transportation of the Republic of Indonesia. Regulation Number 96 of 2015 about Guidelines for the Implementation of Management Activities and Traffic Engineering. Jakarta: Ministry of Transportation, 2015.

[18] Planung Transport Verkehr AG. VISSIM 5.30-05 User Manual. Karlsruhe, 2011.

[19] P. Collins. Paramics Microsimulation ModellingRTA Manual. New South Wales Government. USA, 2009.

[20] Directorate General of Highways. Indonesia Road Capacity Manual (MKJI). Jakarta: Directorate General of Highways, 1997.

[21] Planung Transport Verkehr AG. PTV VISSIM 11 User Manual. Karlsruhe, 2018. 